\section{China: a modern Machiavellian state}

At 11 p.m. Hong Kong time on 30 June 2020, a new national security law entered into force, inter alia criminalizing criticism of the government. It attracted great attention from the West, especially the United Kingdom (UK), as a clear abrogation of the provisions, notably the Basic Law, of the Joint Declaration on the Question of Hong Kong, signed in 1984 by the British and Chinese governments. Fundamental to this Declaration was the principal of "one country, two systems", the two systems being the socialist (as practised in the rest of the People's Republic of China (PRC) — "socialism with Chinese characteristics") and the capitalist (as was previously practised in Hong Kong up until the transfer of sovereignty in 1997 from the UK to the PRC, and which still is practised in the UK and elsewhere).

More succinctly, the two systems might be called dictatorship or totalitarianism and freedom, the latter being construed as freedom under the law (as in the UK). When the British foreign secretary, Malcolm Rifkind, met his Chinese counterpart Qian Qichen in 1996, the latter assured Rifkind that "China, too, believes in the rule of law-in China, the people must obey the law"; revealingly, he was apparently unable to grasp the concept that government must also be under the law, which Rifkind went on to raise [1].

"Dictatorship" and "totalitarianism" are often used in the West as bogey words to evoke hostility. In fact, the two systems are those outlined by Machiavelli almost 500 years ago $[2,3]$. They are two ethical systems based on the preëminence of, respectively, the success of society and individual autonomy. Each has its own merits; Machiavelli clearly favoured the former system but, as I have pointed out elsewhere [4], its attraction probably rests on societies being organized as relatively small (at most a few hundred thousand citizens) autonomous entities, which allow the full potential of the creative innovators within a society to be realized. Modern China is of course much, much bigger but it has achieved a certain unity thanks to the discipline of the Chinese Communist Party (CCP) and its success is manifested in the croissance fulgurante (of GDP) since 1980, albeit at a heavy price in other respects, such as environmental degradation [5]. It is perhaps surprising that China is now so overwhelmingly identified with the system of societal or state preëminence, when Lin Yutang has declared that "The Chinese are a nation of individualists" [6]. Be that as it may, it is doubtless due to the individual autonomy so prized in the West that, after a millennium of Chinese supremacy (AD 300-1300), the West was able to begin its millennium of supremacy [7]. Above all, science gave the West its ascendancy; whereas ancient Taoist ideas in China considered nature to be fundamentally inscrutable, making it futile to investigate it systematically, in the West the idea of a divine ordering principle was embraced and it did make sense, as Albert Einstein remarked, to "want to know how God created this world ... I want to know His thoughts, the rest are details" [8]. ${ }^{1}$ By the early 19th century the discrepancy between the power of a small, advanced Western nation, Great Britain, and the mighty Celestial Kingdom had become so great that it was relatively easy for the former to defeat the latter in the first Opium War (1839-42); as late as 1839 the Imperial Commissioner, Lin Tsê-hsü, appointed to suppress the opium trade, had written to Queen Victoria giving her instructions for what Britain should do to help [10]; the notion of China as the hub of the universe and its emperor the universal monarch was still maintained, although since the 15th century, when Zheng He had indeed led large naval expeditions around the world to collect tribute, it no longer had much relationship with reality.

The picture today is very different. Perhaps the Cultural Revolution (1966-76) was at least partly successful in its avowed aim of erasing the past. China adopted Western methods of doing science, possibly superficially but nevertheless effectively enough to enable dramatic progress in engineering. World hegemony again appears to be the goal, not least through the "four Bs"China as a booster for world economic growth; a builder of a community with a shared future for mankind ("harmonious global governance" is often mentioned); a backer of the existing international order; and with the Belt and Road Initiative, in which foreign countries can receive loans for developing infrastructure, usually built by China. Sun Yat-sen's maxim "The trend of the times moves on like a mighty river. It is our choice to go along and prosper, or go against it and perish" is often quoted by government officials. More constructively than the legacy of the Cultural Revolution, talk is now of "using the past to serve the present". "Gunboat diplomacy" is vigorously repudiated [11].

These are fine words and are doubtless intended to evoke warm, friendly feelings. Many individuals and institutions in the UK are already overtly sinophilic. Perhaps there are still memories of the "golden era" in bilateral relations between Britain and China proclaimed just before President Xi Jinping's visit to Britain in

${ }^{1}$ Strangely, nowadays this legacy is repudiated by many scientists [9]. 
October 2015. We know that every cause has its sycophants; in some cases there may be an ideological attachment, but in many others the route is to be found in venality. For example, the China Centre and China/UK Global Issues Dialogue Centre at Jesus College, Cambridge, which are effusive in their praise of China, have received large sums of money from the Chinese government. One is reminded of "the English professors, who fell prostrate in adoration before the prosperity of cotton-spinners" [12].

But does the "mighty river" really suit the mentality of the West? Galileo, Newton, Brunel, Planck, Einstein and countless others did not make their discoveries and inventions by "going along and prospering". On the contrary theirs were triumphs of individual autonomy. But individual autonomy is not in good shape nowadays in the West. In science it has been steadily eroded during the past few decades by the activities of the research councils and research assessment exercises, which firmly favour the "mighty river" and exclude anything that smacks of originality and innovation [13]. Since the resources available to scientists nowadays largely depend on such bodies, the general level of inventiveness has greatly declined. ${ }^{2}$ The Soviet Union never adopted that system, which is perhaps why it managed to hold its own in, at least, the physical sciences and mathematics, despite its economic development being behind that of the West. Beyond science, the general freedom of expression that was taken for granted, at least in Britain, less so on the European continent, has become petrified by "political correctness".

The massive erosion of individual autonomy is being enormously assisted by "small screen technology" (SST) - the mobile devices to which the vast majority of mankind has become addicted. Tracking and tracing every move and every action of an individual of course perfectly suits a totalitarian system, and modern technology means that it can all be done essentially automatically, without the onerous surveillance by people that ended up wrecking the economies of Yugoslavia and other Eastern European countries. Added to that is SST's erosion of the ability of human beings to extract information efficiently from a source, and write clearly, effectively and succinctly [15], with the result that citizens become incapable of coherently criticizing their government, even if they wanted to.

If we see our future as dominated by SST, then in effect we have renounced individual autonomy and almost by default have embraced the alternative ethical system, giving preëminence to the success of society.
There is already talk of compulsory universal vaccination against Covid-19, and doubtless its cousin, eugenics, will resurface in some form or another. Ironically enough the controversy surrounding Huawei's involvement in building the $5 \mathrm{G}$ network, exacerbated because of the new law in Hong Kong, disappears - if we embrace SST we might just as well embrace Huawei, which can doubtless accomplish the job cost-effectively. In any case, China's aggressive actions in Hong Kong are no worse than those enacted by Britain almost 200 years ago around Hong Kong and Canton; and other actions, such as the invasion and conquest of Tibet, have similarly deplorable counterparts such as the invasion and conquest of Hawai'i by the USA. Advocates of individual autonomy will always oppose groupings into larger units, especially when they are enacted by force.

A possibly decisive threat to the long-term survival of a totalitarian system is that there is not enough freedom to allow creation and innovation to continue $[5,16]$. At present, the innovators and creators, who actually constitute a very small proportion of the population of a modern large state [4], can benefit from mass technologies (e.g., very powerful laptop computers developed for popular gaming, which can be used for calculations) that would otherwise be unavailable or unaffordable. Provided they are not forced to become entrained in the "mighty river", the creators and innovators may even be able to work more effectively than in a simpler, smaller society. It remains to be seen how long they can thus continue, unimpeded, in their niche.

J.J. RAMSDEN

\section{References}

1. M. Rifkind, Hong Kong's freedom is vanishing in front of us. Daily Telegraph (29 May 2020).

2. N. Machiavelli, Il Principe. Milan: Rizzoli (1979) (first published in 1532).

3. I. Berlin, The originality of Machiavelli. In: Against the Current, pp. 25-79. New York: Viking Press (1980).

4. J.J. Ramsden, A.G. Mamalis and N.T. Athanassoulis, The ethics of sustainability. J. Biol. Phys. Chem. 18 (2018) 154-163.

5. T. Toth-Fejel, Irresistible forces $v s$ immovable objects: when China develops Productive Nanosystems. Nanotechnol. Perceptions 4 (2008) 113-132.

6. Lin Yutang, My Country and My People, ch. 6. London: Heinemann (1939).

7. Y.-F. Tuan, Cultural pluralism and technology. Geogr. Rev. 79(1989) 269-279.

8. R.W. Clark, Einstein: The Life and Times, an Illustrated Biography, p. 19. New York: Abrams (1984).

\footnotetext{
2 The ever more strident activities of government organizations such as Innovate UK [14] thereby appear as truly Orwellian.
} 
9. M. Stirrat and R.E. Cornwell, Eminent scientists reject the supernatural: a survey of the Fellows of the Royal Society. Evolution Education Outreach 6 (2013) 33.

10. M. Collis, Foreign Mud, ch. 4(x). London: Faber (1946).

11. Liu Xiaoming, 'Gunboat diplomacy' does not promote peace. Daily Telegraph (20 March 2019).

12. F.S. Oliver, Ordeal by Battle, 2nd edn, p. 184. London: Macmillan (1915).

13. D. Gillies, Lessons from the history and philosophy of science for research assessment systems. J. Biol. Phys. Chem. 10 (2010) 158-164.

14. G.R. Evans, Funding science: A new law, new arrangements. J. Biol. Phys. Chem. 17 (2017) 33-37.

15. P. Inson, Small screens, reading and literacy: examinations and our expectations of young people. Nanotechnol. Perceptions 16 (2020) 71-80.

16. G.P. Thomson, The Strategy of Research (Fourth Fawley Foundation Lecture), p. 17. University of Southampton(1957). 